\title{
PANEL DYSKUSYJNY REKTORÓW UCZELNI KRAKOWSKICH
}

Ks. prof. Wojciech Zyzak: W tym roku jako przewodni temat Dni Jana Pawła II wybraliśmy „uniwersytet” i w związku z tym chciałbym podzielić się refleksją na temat uczelni w kontekście postaci świętego, o którym Jan Paweł II często mówił i który nas wszystkich łączy. Chodzi o świętego z czasów, kiedy jeszcze nasze uczelnie były, jakby u korzenia, połączone, czyli o Jana Kantego. Jeśli mówimy o uniwersytecie, to przede wszystkim mamy na myśli słowo universitas. Pięknie wyraża tę ideę konfesja św. Jana Kantego w kościele św. Anny, gdzie cztery postacie podtrzymujące jego trumnę, czyli teologia, filozofia, prawo i medycyna wyrażają tę pełnię, tę universitas właśnie, którą my tutaj w Krakowie możemy osiągnąć tylko wspólnie, jako uczelnie skupione w Kolegium Rektorów Szkół Wyższych Krakowa. W związku z tym chciałem się podzielić też taką radością: mianowicie kapituła nagrody Totus, ustanowionej przez Konferencję Episkopatu Polski i związanej ściśle $z$ dziedzictwem św. Jana Pawła II, nominowała w tym roku do tej prestiżowej nagrody właśnie tę naszą inicjatywę uczelni krakowskich. Myślę, że to jest nasz wspólny sukces, może niewielki, ale nasz wspólny. Mam nadzieję, że w przyszłości też będziemy te nagrody otrzymywać. Universitas, o której mówiłem przed chwilą, stanowi jeden z najistotniejszych wymiarów uniwersytetu, wyrażający się w tym, iż wszystkie dyscypliny, które uprawiamy na naszych uczelniach, budują jedność. Tylko też w ramach naszego kolegium uosobiamy tę całość.

Św. Jan Kanty wskazuje także na inne ważne wymiary uniwersytetu. Uniwersytet jest mianowicie według niego społecznością wszystkich, w tym sensie, że jest wspólnotą profesorów i studentów. W życiorysie św. Jana Kantego jest taki epizod, który - myślę - jest wyjątkowy. Kiedy Jan Kanty wrócił ze studiów, tu w Krakowie był profesorem filozofii, ale wtedy zapisał się też na studia teologiczne. Był więc wyjątkowym przykładem profesora i studenta w jednej osobie. A to nam stale przypomina, że na naszych uczelniach jesteśmy nauczycielami, ale też pozostajemy zawsze uczniami, i że przez całe życie musimy się uczyć. Św. Jan Kanty miał wówczas około czterdziestu lat. 
Trzeci wymiar, na który Jan Paweł II często zwracał uwagę w refleksji o uniwersytecie, to cel jego działania, istota jego misji. Ostatecznie jest to radość z prawdy veritatis gaudium, jednak św. Jan Kanty wypowiadając się o tym, po co pracował na uczelni, podkreślał jeszcze jeden aspekt, precyzując, iż czyni to także dla zbudowania siebie, czyli dla wewnętrznego pogłębienia swojej osobowości. Pracował więc dla pożytku swojego i dla pożytku innych, a zatem podejmował tę aktywność z miłości do drugiego człowieka. W jednym z zapisków zanotował, że czynił tak także po to, żeby uniknąć nudy i próżności Myślę, że to też jest nadzwyczaj aktualne dla nas, dla naszej pracy na uczelni.

Trzeci wymiar tej uniwersyteckości tworzy solidność, do której nas zachęca św. Jan Kanty. Wiąże się ona z pewnym wydarzeniem w jego życiu, kiedy wybrano go proboszczem w Olkuszu, ale Jan Kanty dość szybko zrezygnował z tej funkcji, bo zrozumiał, że trudno mu połączyć funkcję administracyjną z prawdziwą pracą naukową i badawczą. To jest też jakieś wyzwanie dla nas, bo św. Jan Kanty mówi, że lepiej się skupić na czymś jednym i zrobić to solidnie i dogłębnie, niż rozpraszać się przez całe życie, co chyba dziś jest głównym problemem naszych uczelni.

I wreszcie ostatnia myśl wypływająca z namysłu nad postacią i działalnością Jana z Kęt przynosi refleksję o pewnym poczuciu niespełnienia, które musiało być jego udziałem. Zawsze mnie uderza w życiu św. Jana Kantego to, że pracował przez czterdzieści lat głównie, jak wiemy, przepisując ręcznie księgi. I na krótko przed jego śmiercią do Krakowa dotarła pierwsza księga drukowana, czyli wynalazek Gutenberga. Myślę, że św. Jan Kanty wtedy zrozumiał, że ten cały jego wysiłek życia - przepisywanie ręcznie - w zasadzie nie miał sensu. Świat poszedł dalej technika się rozwinęła i on musiał to przyjąć jako pewne wyzwanie. I to jest też dla nas wszystkich wyzwanie, przypominające nam o tym, że nasza uniwersyteckość polega też na świadomości, że uprawiamy naukę tworzymy ją, rozwijamy badania w jakimś określonym momencie historii, ale nie wszystko się od nas zaczyna i nie wszystko się na nas kończy.

Bardzo serdecznie dziękuję, wszystkim, którzy przyczynili się do tej kolejnej edycji Dni Jana Pawła II, tak istotnej, dotyczącej „Uniwersytetu”.

Ks. kard. Stanisław Dziwisz: W programie mnie nie ma, ale jestem. Dlatego jestem bo Magnificencja zaprosił mnie, żeby jednak tutaj być i to jest mój obowiązek. Mieszkam w Krakowie po przybyciu z Rzymu, gdzie byłem dwadzieścia siedem lat z Janem Pawłem II, a wcześniej jeszcze tutaj dwanaście lat. Mogę powiedzieć, że uniwersytet w ogóle, a Uniwersytet Jagielloński w szczególności, był dla niego czymś wyjątkowym. Często wracał w rozmowach do tego uniwersytetu. Miał ogromny szacunek do instytucji, ale także do profesorów, wykładowców. Często swoich profesorów wspominał. On właściwie rozpoczął swoje studia tutaj, na polonistyce. Potem przyszła też i habilitacja, był ostatnim wypromowanym 
docentem na Wydziale Teologicznym. Bóg zapłać, bardzo dziękuję, że uczelnie krakowskie podjęły to zobowiązanie, aby kontynuować to wszystko, co nam przekazał Jan Paweł II. Jego dziedzictwo jest ogromne. Pogłębić i przekazać. Za to też bardzo dziękuję, że są te Dni Jana Pawła II. Myślę, że ich organizacja to jest obowiązek, zadanie i przywilej Krakowa. Już teraz proszę, aby państwo rektorzy podjęli właśnie taką decyzję, aby co roku kontynuować te Dni dla dobra nauki, ale także dla dobra studentów, środowiska krakowskiego i Kościoła krakowskiego.

O. prof. Jarosław Kupczak OP: Bardzo dziękuję Eminencji ks. Kardynałowi, z całą pewnością na wszystkich wydarzeniach dotyczących Jana Pawła II Ks. Kardynał jest nie tylko mile widziany jako pierwszy gość, ale zawsze jest przez nas uważany za współgospodarza, takiego, który tak naprawdę zawsze jest widziany jako jeden z głównych współorganizatorów, tak że zawsze bardzo dziękujemy za obecność.

Szanowni Państwo, rozpoczniemy teraz pierwszą część naszej debaty rektorów, poprowadzi ją pani dr Paulina Guzik, adiunkt na UPJP II, z Wydziału Nauk Społecznych. Pani doktor jest też dziennikarką prowadzącą program w TVP. Będzie moderowała pierwszą część naszego posiedzenia. Proszę bardzo, Pani Doktor.

Dr Paulina Guzik: Ojcze profesorze, bardzo serdecznie dziękuję przede wszystkim za zaproszenie, to jest dla mnie ogromny zaszczyt, że po raz pierwszy w tym miejscu na Dniach Jana Pawła II mogę do państwa przemówić, choć niestety z lekką niedyspozycją głosu. Chciałabym najpierw przytoczyć słowa pana profesora Stanisława Grygiela, który ostatnio w Rzymie, po obejrzeniu filmu dokumentalnego, wyprodukowanego na Uniwersytecie Papieskim dla TVP, powiedział po jego emisji, że chodzi o rzeczy fundamentalne, bez których nie warto żyć, nie warto myśleć i nie warto kochać. I to były słowa o Janie Pawle II, o jego życiu i związku z nauką. To niezwykle cenne, że są na tej sali osoby posiadające osobiste wspomnienia spotkań z ojcem św., jest pan profesor Ziejka, który, mam nadzieję opowie kiedyś o swoich wszystkich spotkaniach z ojcem świętym, czy to w Castel Gandolfo, czy w Watykanie, czy w Krakowie. W jaki sposób papież odbywał te spotkania z naukowcami, o czym z nimi rozmawiał, jak bardzo pasjonował się nauką, jak bardzo pasjonował się życiem uniwersytetów. My dziennikarze mamy tendencję do skracania wszystkiego w telewizyjne tzw. „setki”, czyli krótkie wypowiedzi i tweety. Skracając w tweecie wypowiedź pana profesora - wspaniały wy$k^{k \nmid a d}{ }^{1}$, można by zapytać, czy uniwersytety mamy sprowadzić do roli producentów patentów? Jednoznaczne przesłanie Jana Pawła II jest takie, że uniwersytet ma przede wszystkim formować młodych ludzi poprzez moralny autorytet.

\footnotetext{
${ }^{1}$ Zamieszczony w pierwszej części niniejszej książki, s. 9.
} 
A teraz bardzo serdecznie zapraszam trzech rektorów krakowskich uczelni:

- Pana profesora dr hab. n. med. Wojciecha Nowaka, naszego gospodarza i rektora Uniwersytetu Jagiellońskiego,

- Pana profesora dr hab. inż. Jana Kaziora, rektora Politechniki Krakowskiej

- Pana profesora dr hab. Stanisława Krawczyńskiego, rektora Akademii Muzycznej w Krakowie.

Nadszedł czas proszę Państwa na kontynuację tego, co przedstawił nam pan profesor Franciszek Ziejka. Profesor Ziejka miedzy innymi zastanawiał się, kim byłby Jan Paweł II, gdyby nie został papieżem, więc zacznijmy w krótkich wystąpieniach od tego, czym byłyby nasze uniwersytety, gdyby nie Jan Paweł II, który był papieżem i absolwentem jednego z nich, Uniwersytetu Jagiellońskiego. Panie Rektorze bardzo serdecznie proszę o wypowiedź.

Prof. dr hab. med. Wojciech Nowak: Ja może troszeczkę odejdę od tych pytań, bo wykład pana prof. Ziejki, mojego wielkiego poprzednika, pokazał bardzo ważną rzecz. Pokazał mianowicie rolę Jana Pawła II w sytuacji sprzed trzydziestu lat: jak wówczas wyglądała Europa, jak wyglądała Polska, jak wyglądał świat, jak wyglądały uniwersytety? To jest nieporównywalne z czasem obecnym, te słowa, które wtedy wypowiadał, miały ogromne znaczenie. Miejcie państwo świadomość nie było Internetu, a Steve Jobs jeszcze nie spowodował, że wszyscy jesteśmy uzależnieni od telefonu komórkowego i posiadamy nieograniczone możliwości komunikacji z całym światem. To było wtedy niewyobrażalne, żeby w każdej chwili mieć możność połączenia się z Australią i przedyskutowania problemów. Tego wszystkiego wówczas nie było. A ten człowiek, w swojej mądrości i przenikliwości, rozumiał jakie niebezpieczne procesy zaczynają podkopywać wyższe uczelnie, naruszając ich fundamenty, fundamenty zasad, wedle których dotychczas funkcjonowały i którymi się kierowały. Jestem niezmiernie ciekaw, jakby Jan Paweł II ocenił Internet. Pod koniec pontyfikatu były przecież takie momenty, że bardzo interesował się informatyką. Jego następca, Benedykt XVI, nawet chyba rozpoczął erę kontaktu przez media, a papież Franciszek chętnie wykorzystuje media społecznościowe. Nie można o tym zapomnieć Anno Domini 2020.

Pan prof. Ziejka wspomniał słusznie o konflikcie badań podstawowych i tzw. badań wdrożeniowych, kończących się patentem, ale bardzo proszę dziennikarzy, by nie mylili pojęć. To jest tak jakbyśmy mówili o rowerze i bolidzie mercedesa. Jeden i drugi jedzie, ale to nie jest to samo. Szanowni Państwo, przecież nie dlatego elektrycznością zajmował się Rutherford, żeby można było produkować żarówki. Nie dlatego fizycy rozbijali atom, żeby produkować bomby. A Roentgen nie po to odkrył promienie jonizujące, żeby zarabiać na badaniach radiologicznych. Nigdy czegoś takiego nie było, nie ma i nie będzie. Oczywiście, że to się uzupełnia. A to, że z badań podstawowych wynikają genialne potem różne rzeczy wdrożeniowe, 
to, co pani powiedziała, patenty, to jest rozwój cywilizacji. Wróćmy jednak do Jana Pawła II, bowiem to jest najistotniejsze.

Szanowni Państwo, przytoczone przed chwilą przez prof. Ziejkę cytaty, stały się codzienną refleksją środowiska uniwersyteckiego i niemal każdy z nas je dobrze zna. Ja zadałem sobie dawno temu takie pytanie. Karol Wojtyła to był nasz student Wydziału Polonistyki, w czasach bardzo trudnych, czasach wojny. Jak państwo wiecie, potem był studentem Wydziału Teologicznego, bo jeszcze w tamtych czasach ten wydział był w Uniwersytecie Jagiellońskim. Każdy z nas ma w swoim życiorysie taki moment, gdzie zastanawia się nad pewnymi tematami typu: co znaczy uniwersytet, co znaczy kształtować postawę obywatelską, patriotyczną, co to znaczy? Zadaję sobie to pytanie, kto taki wpływ wywarł na Karola Wojtyłę, wtedy jeszcze studenta? I cofnąłem się do jego encyklik, żeby zobaczyć, kogo najczęściej, w tych tematach universitas cytuje. Jest taki człowiek, doskonale Państwu znany, mianowicie prof. Kazimierz Twardowski. Nie był on profesorem Uniwersytetu Jagiellońskiego, lecz uniwersytetu lwowskiego, był twórcą filozofii lwowskiej. W 1932 roku otrzymał w Poznaniu doktorat honoris causa i z tej okazji wygłosił wspaniały wykład. I papież właśnie jego cytował, przytaczając fragmenty tamtego wykładu. Posłuchajcie Państwo, to ten słynny wykład „o dostojeństwie uniwersytetu”:

Owo dostojeństwo uznawał Twardowski za najwyższą akademicką wartość, płynącą nie tylko z sędziwego wieku i chlubnej tradycji uczelni, takiej jak nasza, ale upatrywał jego źródło, źródło owego dostojeństwa, w samej idei uniwersytetu. Według Twardowskiego zasadniczym zadaniem uniwersytetu jest zdobywanie prawd i prawdopodobieństw naukowych oraz krzewienie umiejętności ich dochodzenia. Rdzeniem i jądrem pracy uniwersyteckiej jest twórczość naukowa zarówno pod względem merytorycznym, jak i metodycznym. Zauważał, że służąc temu celowi uniwersytet promienieje dostojeństwem, tworząc najwyższe wartości intelektualne. Uniwersytet winien uczyć tego sposobu myślenia, który do owej wiedzy i prawdy prowadzi. Podkreślił równocześnie, że uniwersytet ma wręcz obowiązek unikać wszystkiego, co by mogło jego niezawisłość nadwyrężyć lub stwarzać chociażby pozory ulegania jakimkolwiek wpływom i dążeniom. Uniwersytet musi przestrzegać należytego dystansu między sobą, a nurtem, który mknie około niego w tzw. życiu dnia codziennego, a więc dystansu do ścierających się prądów społecznych, ekonomicznych, politycznych i wszelkich innych.

To był 1932 rok. Jan Paweł II zapamiętał te słowa i twórczo je rozwinął. Większość z nas, na pewno ja, bardzo dokładnie pamięta te słowa. I zadałem sobie już jako medyk pytanie: jak to się dzieje, że człowiek, taki jak Jan Paweł II mówi prawdy oczywiste, bo przecież dla każdego z nas tu obecnych, swoboda badań naukowych, wolność badań naukowych jest prawdą oczywistą, i jest słyszany? Gdyby większość z nas wyszła na jakieś forum publiczne, to nikt nie zwróciłby uwagi 
na to, co powiemy, wszyscy przeszliby nad tym do porządku dziennego. A jak tę prawdę głosił Jan Paweł II, to wszyscy słyszeli i przynajmniej 80\% nie tylko słyszało, ale i słuchało i to jest ten fenomen, którego nie nauczy żaden, nawet najlepszy uniwersytet, bo to po prostu jest pewien dar. Ja tłumaczę sobie ten fenomen jedną bardzo prostą odpowiedzią. U jego źródeł znajduje się autentyczność. W Janie Pawle II wszyscy wierzący i niewierzący, agnostycy, widzieli autentycznego człowieka. W tym też tkwiła jego największa siła i to jest ta siła, którą i nam, i uniwersytetowi, przekazał.

Dr Paulina Guzik: Bardzo dziękuję panie profesorze. Absolutnie nie było moją intencją krytykowanie tego, że na uniwersytetach powstają patenty. Sama jestem naukowcem na Uniwersytecie Papieskim Jana Pawła II i wiem, że wizjonerstwo pozostaje wielkim zadaniem uniwersytetów. Myślę jednak, że przede wszystkim tutaj wybrzmiało to, że ci genialni naukowcy, którzy tworzyli patenty, byli zazwyczaj dobrze uformowanymi ludźmi. I niezależnie od tego, czy byli fizykami, chemikami, czy lekarzami, byli przede wszystkim humanistami, a naczelną, pierwszą wartością był dla nich człowiek. Przy okazji, odpowiadając na pytanie Pana Profesora o Internet i technologie, to warto wspomnieć wypowiedź Jana Pawła II z 2002 roku, kiedy większość z nas nie korzystała jeszcze powszechnie z Internetu, papież napisał w orędziu na Dzień Środków Społecznego Przekazu: „Kościół podchodzi do tego nowego środka - Internetu, międzyludzkiej komunikacji $\mathrm{z}$ realizmem i zaufaniem. Internet podobnie jak inne narzędzia komunikacji jest środkiem, a nie celem samym w sobie.” I to jest, myślę, też ta wizja Jana Pawła II, że w czasie, kiedy jeszcze nie wszyscy korzystaliśmy on już potrafił w takich słowach o tym napisać.

Mikrofon widzę jest już w rękach pana profesora Krawczyńskiego, zostańmy $\mathrm{w}$ takim razie w nurcie humanistycznym i artystycznym. Panie Profesorze, jak muzyków wciąż inspiruje Jan Paweł II, jak inspiruje Państwa uczelnię?

Prof. Stanisław Krawczyński: Tak, to niezwykle ciekawe pytanie, ale jednocześnie szalenie istotne. Jan Paweł II czuł się silnie związany ze środowiskiem uniwersyteckim. Pozwolę sobie przypomnieć słowa, które wypowiedział w 2002 roku podczas spotkania 17 czerwca na terenie budowy biblioteki Uniwersytetu Papieskiego, później nazwanego jego imieniem. Powiedział wtedy: „Codziennie modlę się za wasze uczelnie”. Niezwykle istotnym jest tu słowo - „codziennie” - pokazuje ono, jak ogromną wagę przywiązywał papież do spraw środowiska akademickiego. „Codziennie”, czyli każdego dnia, znaczy, że miało to dla niego ogromną wagę. Jan Paweł II jako pedagog akademicki, jako profesor przenosił w swoją późniejszą codzienność wiele elementów z życia akademickiego. To było coś, co, my jako nauczyciele akademiccy przejmowaliśmy podświadomie, ale zawsze uznając 
za wzorcowe. Uniwersytet - universitas - to wspólnota, społeczność; tak myślał o środowisku akademickim Jan Paweł II i przekładał to na zwykłą codzienność, zwłaszcza w okresie, gdy spełniał profesorskie obowiązki.

Chęć tworzenia wspólnoty była inspiracją do słynnych spotkań z młodzieżą, wycieczek górskich, wypraw kajakowych... to była próba szukania we wspólnotowej formule relacji mistrz-uczeń, odnalezienia tej zależności oraz niezwykle głębokiego „zanurzenia się" w niej. Dla ojca świętego nie była to relacja dwóch różnych poziomów, lecz wzajemne współistnienie - relacja paralelna, w której uczeń przejmuje od mistrza wiedzę, a mistrz przekazuje ją na poziomie partnerskim, dzięki czemu czyni to najskuteczniej. Oczywiście, w zamian Kardynał Wojtyła otrzymywał od uczniów wielką i niezwykłą miłość.

Przypominam sobie spotkanie z młodzieżą na Skałce podczas pierwszego przyjazdu Jana Pawła II do Polski. Niezwykłym doświadczeniem było już samo oczekiwanie młodzieży na jego pojawienie się. Miałem wtedy szczęście przygotowywać oprawę muzyczną spotkania. Studenci przynieśli zrobiony przez siebie krzyż, który później chcieli postawić w Miasteczku Studenckim. Oczekując na Jana Pawła II, zaczęli w bardzo specyficznej konfiguracji odmawiać różaniec - część modlitwy recytowały kobiety, kolejną część mężczyźni. W tej chwili, pełnej napięcia i oczekiwania, zwracało uwagę, jak wielką siłę osiągnęła modlitwa zróżnicowaniem kolorystycznym, wysokie głosy żeńskie dialogowały z niskimi męskimi. Miałem wrażenie symbolicznego uzupełniania się, silnego połączenia mężczyzn i zespolenia kobiet w tym samym akcie modlitewnym. Ukazywało to zmierzanie do tego samego celu jednolicie i równoległymi drogami. Pamiętam, było to dla mnie niezwykłe przeżycie...a później samo spotkanie z Janem Pawłem II. Jego wypowiedzi, jego niezwykła bezpośredniość i prostota oraz wspomniana umiejętność utrzymywania relacji na jednym poziomie, bez podkreślania swojej wiodącej pozycji. Pamiętam, że przez lata fascynowało mnie to właśnie spotkanie, dzięki niezwykłej sile modlitewnej i więzi z papieżem, która wtedy, nawet bez jego bezpośredniej obecności, została nawiązana i realnie miała miejsce.

Jako ciekawostkę opowiem Państwu o sytuacji, która wydarzyła się później, a związana była z tamtym wydarzeniem oraz postacią, której osobowość, skromność i osiągnięcia artystyczne niezwykle cenię - kompozytorem Wojciechem Kilarem. Był on osobą bardzo religijną, przywiązującą wielką wagę do wszystkiego, co związane $\mathrm{z}$ wiarą $\mathrm{i}$ co tak silnie objawiało się w jego muzyce. Przygotowywałem prawykonanie utworu Angelus Kilara, był to rok 1981, czas trudny, okres stanu wojennego; poprosiłem kompozytora o wskazówki, co do sposobu wykonania dzieła. Pytałem, na co powinienem zwrócić uwagę, pracując nad utworem. A Kilar wtedy powiedział: „ja tak na odległość z Panem nie potrafię". Kompozytor mieszkał w Katowicach, ja w Krakowie; i kontynuował: „to ja przyjadę do Pana, spotkamy się i porozmawiamy”. Podczas spotkania poprosił: „zanim podzielę się swoimi 
przemyśleniami, proszę mi powiedzieć, jakie miał Pan pierwsze skojarzenia z tą kompozycją, gdy ją Pan usłyszał?”. Wtedy opowiedziałem o spotkaniu na Skałce. Pamiętam, że był niezwykle poruszony i powiedział „moim zamiarem nie było tworzenie specyficznej kolorystyki" - w utworze tym fragmenty różańca były dokładnie tak samo wykonane, jak wtedy na Skałce - osobno głosy żeńskie, osobno męskie, znowu żeńskie i tak na przemian. „Natomiast jedno, co muszę Panu powiedzieć: chciałem uzyskać i pokazać niezwykłą siłę tej modlitwy poprzez użycie dwóch różnych barw." W związku z tym zaistniały dwie jak gdyby skrajnie różne sytuacje, a jednak złączone jedną myślą, jedną ideą.

Jan Paweł II w swoim nauczaniu duszpasterskim niezwykle często nawiązywał do myśli zaczerpniętych z nauczania akademickiego. Niejednokrotnie wykorzystywał idee, jakie później stawały się tematami przewodnimi dla poszczególnych Dni jemu poświęconych. A więc na przykład p r a w d a - prawda nie tylko w wymiarze osobistym, prawda, która stwarza moją wiarygodność, ale też prawda w badaniach naukowych, prawda w dochodzeniu do tego, co najistotniejsze, co najważniejsze. Następnie ku lt u r a, która wg. Jana Pawła II była nieodłącznym elementem życia akademickiego, wzbogacającym nasze osobowości. A kultura, to także sztuka, a więc m.in. oczywiście muzyka, to, czym my zajmujemy się w krakowskiej Akademii. I tu chcę wrócić na moment do wydarzenia, które miało miejsce dosłownie chwilę temu. Każdej edycji Dni Jana Pawła II towarzyszy koncert, staramy się pokazać kulturę w jak najszerszym wymiarze. W tym roku udało się to w sposób zupełnie wyjątkowy, co wpisuje się, uważam, w kontynuację dziedzictwa Jana Pawła II - sięgnięcie do szerokiego wymiaru kultury. Podczas koncertu, odbywającego się w kościele św. Piotra i Pawła spotkały się zespoły chóralne wielu uczelni krakowskich: Uniwersytetu Jagiellońskiego, Uniwersytetu Pedagogicznego, Uniwersytetu Ekonomicznego i Międzyuczelnianego Instytutu Muzyki Kościelnej. Zespoły wystąpiły wspólnie z Orkiestrą Akademii Muzycznej w Krakowie. Nie jest istotny $\mathrm{w}$ tej chwili sam program koncertu. Ważna, moim zdaniem, jest idea połączenia kilku społeczności akademickich, stworzenia i podkreślenia wspólnoty, universitas, czyli tego, co pozostawił nam w swojej spuściźnie Jan Paweł II i co tak mocno podkreślał. Jestem głęboko przekonany, że tak niezwykła postać, jaką był Jan Paweł II, swoją osobowością, działaniem, ale i też swoją modlitwą wywarła ogromny wpływ na polskie oraz światowe środowisko akademickie i to jest wielkie dziedzictwo, którego nie wolno nam stracić i nie wolno od niego odejść ani na krok.

Dr Paulina Guzik: Bardzo dziękuję, Panie profesorze. Ogromnie cieszę się, ze przywołał Pan Profesor postać maestro Wojciecha Kilara. Muszę powiedzieć, że kilka dni po nagraniu - pamiętam, wiele lat temu - po nagraniu ks. kardynała Stanisława Dziwisza, nagrywałam wywiad z okazji osiemdziesiątych urodzin Wojciecha Kilara i zapytałam go wtedy: „A czego sobie Maestro życzy z okazji tych 
osiemdziesiątych urodzin?” A on spojrzał na mnie i powiedział: „Wie Pani przywołam słowa jednego paulina z Jasnej Góry, który jak obchodziłem któryś jubileusz (bo właśnie zawsze te jubileusze obchodził właśnie na Jasnej Górze) mówi mi tak: «Wiesz co, życzę ci, żebyś nie zbiskupiał»”. I tym żartobliwym akcentem myślę, że warto przejść do Jana Pawła II, który jako papież zawsze miał dla uczonych otwarte drzwi Pałacu Apostolskiego. Ważne jest to, co powiedział mi ostatnio George Weigel i co powtarzało wielu przyjaciół papieża, on nieustannie słuchał, słuchał i przez te spotkania się uczył.

I teraz pytanie do Pana Profesora z dziedziny technicznej, technologicznej na Politechnice Krakowskiej, jak Państwo czerpiecie z nauki Jana Pawła II? Jak on inspiruje środowisko Politechniki Krakowskie? Czy podobnie jak Akademię Muzyczną? Jak z nauczania papieża humanisty, można wziąć coś dla studentów właśnie tych którzy studiują coś, co jest przyszłością?

Prof. dr hab. inż. Jan Kazior: Na wstępie chciałbym szczególnie podkreślić, że społeczność akademicka Politechniki Krakowskiej ma wciąż bardzo bliskie więzy z Janem Pawłem II. Kiedy Jan Paweł II był wikarym w bazylice św. Floriana jednocześnie był opiekunem akademickim studentów Politechniki Krakowskiej. To właśnie w tym okresie nawiązały się bardzo bliskie relacje Jana Pawła II ze społecznością akademicką. Ośmielę się nawet powiedzieć, że były to bardzo bliskie przyjaźnie zawiązane w czasie wypraw na jeziora, kiedy Karol Wojtyła jeszcze jako biskup, a potem jako kardynał odpoczywał w towarzystwie studentów, ale i profesorów z Politechniki Krakowskiej. Wymienię tutaj tylko jednego błogosławionego profesora, Jerzego Ciesielskiego. Dla naszej społeczności akademickiej szczególnym wydarzeniem była data 17 czerwca 1999 roku, kiedy po mszy papieskiej na Wawelu odbyło się spotkanie ze społecznością akademicką Politechniki Krakowskiej, podczas którego papież odebrał godność senatora i profesora Politechniki Krakowskiej. To dla nas było szczególne wyróżnienie, ale i również szczególne zobowiązanie do pogłębienia i zrozumienia tych myśli i wartości, które przekazywał nam Jan Paweł II. Nie tylko jako głowa Kościoła, ale może przede wszystkim jako wybitny filozof i jako naukowiec. Trudno mi sobie wyobrazić jak wyglądałaby dzisiaj Politechnika Krakowska bez tych szczególnych i głębokich więzi łączących naszą społeczność z Janem Pawłem II.

Ustosunkowując się do pytania Pani Redaktor, jak Jan Paweł II odniósłby się do współczesności? Jakie zdanie miałby na temat Internetu? Wydaje mi się, że te myśli, które przekazywał nam Jan Paweł II są na tyle głębokie, że możemy również znaleźć odpowiedź na to pytanie. Mianowicie obserwujemy, szczególnie na początku XXI wieku, ogromny rozwój i postęp technologiczny i zadajemy sobie pytanie o granice eksperymentu i roli człowieka, roli pracownika naukowego w tych badaniach. Dokąd my zdążamy i jakie są granice tych naszych badań? I tutaj nawet 
przeglądającstu tę antologię, którą otrzymaliśmy, wchodząc na dzisiejsze spotkanie, można znaleźć fragment zawierający szereg myśli, które Jan Paweł II dwadzieścia lat temu przekazał w czasie jednego ze spotkań z rektorami polskich uczelni. Zwrócił wtedy szczególną uwagę na specyficzną rolę pracowników naukowych prowadzących badania eksperymentalne przyczyniające się do rozwoju nowych technologii. Pytał wówczas o pewne granice i odpowiedzialność, za te badania. Bo trzeba powiedzieć, że rozwój technologii, szczególnie technologii informatycznych, stanowiący przedmiot fascynacji nie tylko dla młodzieży, ale i również dla nas, generuje pewne zagrożenia. Proszę zwrócić uwagę, że ten nieograniczony postęp technologiczny rodzi przecież określone lęki i obawy, a w niektórych wypadkach wręcz czujemy się zagrożeni. I żeby podać konkretny przykład, przywołam hasło: cyberbezpieczeństwo. Ja nawet nie wiem, czy w tej chwili nie wydajemy więcej pieniędzy na cyberbezpieczeństwo, niż na rozwój informatyki i rozwój technologii cyfrowych. Bo ten rozwój w wielu przypadkach stanowi dla nas ogromne zagrożenie. Jan Paweł II na poziomie ogólnych rozstrzygnięć czy wskazań na te pytania odpowiedział. Jaka jest w tym zakresie odpowiedzialność pracownika naukowego? I tutaj papież zwrócił szczególną uwagę na to, że pracownik naukowy powinien przestrzegać zasad etyki i moralności. Człowiek rozwijając technologie, powinien zachowywać się $\mathrm{w}$ ten sposób, żeby z nich mądrze korzystać, a nie doprowadzać do sytuacji, że rozwój technologii będzie generował zagrożenia, w wyniku których człowiek straci poczucie bezpieczeństwa. Rzecz nie dotyczy tylko rozwoju technologii, ale zwróćmy uwagę, że rozwój technologii również prowadzi do niszczenia środowiska, w którym żyjemy i tego też jesteśmy świadkami. Postęp technologiczny prowadzi do zmian klimatu, ale i również do zmian jakości powietrza i generalnie środowiska, w którym żyjemy.

Reasumując, wydaje mi się, że słuchając wypowiedzi Jana Pawła II przy różnych okazjach, znajdujemy na te pytania taką odpowiedź, że w swoich badaniach musimy się kierować etyką, musimy się kierować moralnością, a uzyskane wyniki powinny zawsze służyć rozwojowi człowieka, a nie przyczyniać się do tego, że w wyniku rozwoju technologii człowiek będzie się czuł ograniczony, zagrożony, nie będzie się rozwijał. Wydaje mi się, że Politechnika Krakowska zawsze pamięta o Janie Pawle II. Jest takim naszym sumieniem, do którego w trudnych chwilach nasi pracownicy i studenci zawsze się odnoszą.

Dr Paulina Guzik: Bardzo dziękuję, Panie Profesorze. Myślę, że drugi duch patronujący naszym rozmowom, tak to tutaj czujemy w tej sali, to jest sługa Boży Jerzy Ciesielski, genialny inżynier i profesor Politechniki Krakowskiej, o którego beatyfikację cały czas wszyscy się tutaj w Krakowie modlimy. Chciałabym przywołać jeszcze słowa Jana Pawła II z warszawskiego kościoła św. Anny wypowiedziane w roku 1979, kiedy Jan Paweł II po ważnych słowach, iż człowieka trzeba 
mierzyć miarą serca, która idzie przed wszystkim, przed inteligencją, rozumem i wykształceniem mówił tak:

Tak jak kiedyś mój rodzony ojciec włożył mi w rękę książkę i pokazał w niej modlitwę o dary Ducha Świętego, tak dzisiaj ja, którego również nazywacie ojcem, pragnę modlić się z warszawską i polską młodzieżą akademicką o dar mądrości, o dar rozumu, o dar umiejętności, czyli wiedzy, o dar rady, o dar męstwa, o dar pobożności.I teraz kolejne pytanie do panów rektorów. Jaki dar polskie uczelnie mogą dać dzisiaj polskiej młodzieży? Jakie największe zadanie stoi dzisiaj przed nami, także w obliczu stulecia urodzin Jana Pawła II, aby pokoleniu, które nie pamięta osobiście Jana Pawła II przekazać ten ogrom mądrości, którą nam zostawił, to ogromne dziedzictwo, które trudno w ogóle zmierzyć?

Prof. Wojciech Nowak: Szanowni Państwo, tak się składa, że mamy jeszcze tylko pięć minut, a to jest bardzo duże pytanie, bardzo trudne pytanie. Ale też odpowiedź na nie wydaje się bardzo jednoznaczna i zarazem prosta. Nauczanie Jana Pawła II jest dla nas przekonywające i trafia do nas, bo jest autentyczne, bo jest prawdziwe. Pani Redaktor powiedziała o tym spotkaniu w Warszawie, że były tam tłumy młodzieży, bo one chciały przyjść, bo one chciały Jana Pawła II słuchać, bo był autentyczny. To naprawdę jest warunek sine qua non. Bo można chcieć być słuchanym i nic z tego nie wynika. Jan Paweł II był autentyczny. Tak jak mówiłem zaraz będzie przerwa, więc pozwólcie Państwo, że odejdę na chwilę od tej bardzo wysokiej nuty w rozmowie na temat Jana Pawła II. Bo nie zapominajmy, że w tej autentyczności to był wspaniały, ale i zwyczajny człowiek, z którym rozmowa była bardzo bezpośrednia, którego poczucie humoru było niewyobrażalne. Nigdy nie zapomnę sceny, kiedy Jan Paweł II odwiedzał dziedziniec Collegium Maius. Spotkanie było o godzinie 10.00 i myśmy wszyscy już tam wcześniej stali, a papamobile podjechał gdzieś za minutę dziesiąta. Papież spytał, która jest godzina, kiedy usłyszał, że dziesiąta, powiedział „musimy jeszcze porozmawiać, bo kwadrans akademicki obowiązuje nawet papieża”. Powiedział to, gdy tam stało mnóstwo dostojników kościelnych, politycznych, uniwersyteckich.

A pamiętam też, jak byłem w Ameryce, na takim chirurgicznym dużym zjeździe; któraś stacja przeprowadziła wywiad z Janem Pawłem II. Opowiem to Państwu, bo chciałbym tego papieża pokazać bardziej bezpośrednio, jako człowieka, a mniej od strony uniwersyteckiej. Otóż, prowadząca wywiad dziennikarka, nie pamiętam, która to była, zadała nieśmiertelne pytanie „Ile osób pracuje w Watykanie?”, a on na to po namyśle, odpowiedział „trzy: ja, kardynał Dziwisz, no i może kardynał Casaroli”. Ja to oglądałem nie w Polsce; papież na specyficznym kontynencie amerykańskim, po obaleniu komuny, w szczególnym momencie 
historycznym w taki sposób, z takim wielkim dystansem do siebie, odpowiada na to pytanie, nie pamiętam już której stacji. Taki był Jan Paweł II.

Dr Paulina Guzik: W takim razie bardzo dziękuję, Panie Profesorze i bardzo proszę pana profesora Krawczyńskiego o takie właśnie krótkie słowa podsumowania, być może jakieś osobiste wspomnienie związane z Janem Pawłem II.

Prof. Stanisław Krawczyński: Pan Rektor powiedział, że Jan Paweł II był osobą niezwykle bezpośrednią i taką powiedzmy miłą w kontaktach, więc teraz pozwolę sobie na małe anegdotyczne wspomnienie związane z Janem Pawłem II... Miałem możliwość niejednokrotnego uczestniczenia z nim w różnego rodzaju spotkaniach, m.in. prywatnych w papieskiej kaplicy czy watykańskiej bibliotece. Zawsze podczas tych wydarzeń pojawiał się fotograf. Jednym był Arturo Mari, drugim Alberto Felici, którzy dokumentowali spotkanie ogromną ilością zdjęć. Zdjęcia te krążyły później w różnych środowiskach, jako ilustracje z życia Jana Pawła II. Jednym ze spotkań była audiencja w sali Klementyńskiej, gdzie z ojcem świętym spotkały się: chór chłopięcy i chór mieszany Filharmonii Krakowskiej oraz chór Polskiego Radia. Spotkanie rozpoczęło się od prezentacji uczestników, jakiej dokonywałem razem panią profesor Bronisławą Wietrzny (prowadzącą chór chłopięcy), która była starsza ode mnie o kilkanaście lat. Mieliśmy powiedzieć kilka słów do papieża, ja wręczałem ojcu świętemu album z litografiami kościoła krakowskiego, ona bukiet biało-czerwonych róż. I oczywiście, jak zwykle, zdjęcia, zdjęcia, zdjęcia... Po latach, już w Krakowie, przechodząc obok kościoła św. Katarzyny, zauważyłem napis „Wystawa fotograficzna Polacy u Ojca Świętego". Pomyślałem, warto oglądnąć... na klasztornych krużgankach zostały wyeksponowane fotogramy uszeregowane tematycznie: górnicy u Ojca Świętego, lekarze u Ojca Świętego, nauczyciele u Ojca Świętego. Już z daleka rzucało się w oczy znajome zdjęcie, na którym stoję z albumem, obok pani profesor Wietrzny trzymającej naręcze kwiatów; zdjęcie podpisano „Młode małżeństwa u Ojca Świętego". Tak więc, każde spotkanie z Janem Pawłem II było wyjątkowe; najczęściej w wymiarze duchowym, modlitewnym, niezwykle osobistym ale też czasami humorystycznym.

Dr Paulina Guzik: To jeszcze z takich, króciutkich wspomnień. Ksiądz profesor Heller ostatnio na gali wręczenia „Totusów”, zresztą serdeczne gratulacje dla tej nominacji, absolutnie zasłużona po tylu latach przypominania nauki Jana Pawła II... Ksiądz prof. Heller powiedział, że zanim Jan Paweł II został papieżem i on chciał się zajmować kosmosem. „Mówili mi, że nie możesz zajmować się kosmosem, bo szkoda księdza, musisz się zajmować teologią." I podsumował tak: „jak Jan Paweł II został papieżem nie było takich problemów". Proszę bardzo, po wspo- 
mnieniu ks. prof. Hellera, naukowca, widać, że na państwa uczelni zajmujecie się sprawami, które dla humanistów są kosmiczne. Bardzo prosimy o wspomnienia pana profesora Jana Kaziora.

Prof. Jan Kazior: Ja z pewnością zaliczam się do pokolenia Jana Pawła II, ale w przeciwieństwie do moich kolegów, nie miałem możliwości tak bezpośrednich spotkań z Karolem Wojtyłą, kiedy był papieżem. Natomiast jako uczeń jednego z liceów krakowskich miałem przywilej, że przyjmowałem na Wawelu sakrament bierzmowania od, jeszcze wtedy chyba biskupa, Karola Wojtyły. Niemniej tak jak mówiłem, Jan Paweł II jest dla społeczności akademickiej tą postacią, która wytycza pewne wartości i pewne cele, do których zdążamy. I niewątpliwie Politechnika Krakowska jest uczelnią techniczną, więc kształcimy inżynierów i wyzwaniem, która jest przed nami jest pytanie, w jaki sposób powinniśmy kształcić inżynierów, którzy w jak najlepszy sposób służyliby społeczeństwu, służyliby ludziom. Zadając sobie to pytanie w tych dyskusjach na różnych posiedzeniach senackich komisji, mógłbym to podsumować w sposób następujący: że czerpiąc z tego bogactwa myśli Jana Pawła II staramy się kształcić w ten sposób, żeby absolwenci Politechniki Krakowskiej, oprócz zdobytej wiedzy przede wszystkim mieli umiejętność samodzielnego myślenia i kreowania tej nowej rzeczywistości w ten sposób, żeby się środowisko technologiczne wokół nas rozwijało, ale i równocześnie służyło człowiekowi i jego rozwojowi. W ten sposób staramy się przekazywać naszą wiedzę; czy nam się udaje - to Państwo sami z pewnością oceniacie i w przyszłości osądzicie. Dziękuję bardzo.

Dr Paulina Guzik: Bardzo dziękujemy, serdecznie dziękuję panom profesorom, zapraszam teraz na chwilę przerwy. Po niej kolejna debata panów rektorów na którą serdecznie zapraszamy, a podsumowując tę część, myślę, że pamiętajmy o Janie Pawle II przede wszystkim jako Człowieku przez duże C. Bardzo dziękuję.

Dr Paulina Guzik: Jan Paweł II nie bał się wchodzić w dialog z tymi, którzy się z nim nie zgadzali i z tymi, z którymi on się nie zgadzał. Prof. Andrea Ricardi, historyk idei, powiedział mi w Rzymie w lutym, że Jan Paweł II to był człowiek, który słuchał szeptów świata. I myślę, że w kontekście wchodzenia w spór także $\mathrm{w}$ tym naszym dialogu to są bardzo ważne słowa.

A teraz zapraszam już kolejnych zapowiedzianych gości. Będą nimi:

- Ks. prof. Wojciech Zyzak, rektor Uniwersytetu Papieskiego Jana Pawła II, 
- Pan prof. Andrzej Chochoł, rektor Uniwersytetu Ekonomicznego w Krakowie oraz

- Pan prof. Kazimierz Karolczak, rektor Uniwersytetu Pedagogicznego w Krakowie.

Na początek tak jak poprzednio, bardzo proszę o odwołanie się do tego jak uczelnie, które Panowie Rektorzy reprezentują odnoszą się do nauki Jana Pawła II. Jak niosą to ogromne, gigantyczne dziedzictwo pozostawione nam przez Jana Pawła II.

Ks. prof. Wojciech Zyzak: To powinno być najłatwiejsze zadanie dla mnie, bo rozumie się samo przez się, że uniwersytet papieski, to nie tylko z racji nazwy Uniwersytet Papieski Jana Pawła II, ale z wszelkich innych powodów ma niejako w swoje DNA wpisane podtrzymywanie, rozwijanie dziedzictwa, tego fenomenu jakim był św. Jan Paweł II. I przygotowałem się, parę rzeczy sobie wypisałem, pewnie to nie jest wszystko, ale $\mathrm{z}$ takich najbardziej aktualnych spraw to oczywiście - my dużo publikujemy. W najbliższym czasie będziemy publikować wraz z Instytutem Dialogu Międzykulturowego dzieła naukowe Karola Wojtyły. To będzie dalsza część tego, co już w środowisku krakowskim zrobiono, czyli wydano dzieła literackie. Tym razem będą to dzieła naukowe, w oczywisty sposób są tam przede wszystkim zaangażowani nasi pracownicy naukowi, bo są to pisma filozoficzne, teologiczne i po części pastoralne. To będzie ponad trzydzieści tomów, a więc wszystko to, co w sposób naukowy opracowywał Karol Wojtyła od 1946 do 1978 roku.

Oczywiście, to jest naturalne, że w takiej uczelni jak nasza działa Ośrodek Badań nad Myślą Jana Pawła II, który prowadzi ojciec Kupczak. Wydaje serię znamienitą, mianowicie Studia nad myślą Jana Pawła II, prowadzi otwarte wykłady „Jan Paweł II. Posługa myślenia”. Ma też u nas na Wydziale Teologicznym Katedrę Antropologii, ale katedra ta pomyślana jest jako antropologia w rozumieniu Jana Pawła II. My też próbujemy, w jakimś sensie oddziaływać trochę szerzej; to jest oczywiste, że na Uniwersytecie Papieskim Jana Pawła II powstaje dużo prac naukowych: czy to magisterskich, czy to doktoratów na podstawie dorobku Jana Pawła II. Powiem też o pewnej inicjatywie, która dla nas jest niezmiernie ważna, a mianowicie Kraków Study Abroad, mamy taki projekt, JPII, który skierowany jest do studentów uczelni amerykańskich, pragnących przyjechać na trzysemestralne spotkania tutaj w Krakowie, żeby zapoznać się z miastem Jana Pawła II, zobaczyć naszą kulturę, trochę nawet pouczyć się języka polskiego - to też im proponujemy ale przede wszystkim, i to jest główna idea, aby rozwijać i zgłębiać dziedzictwo św. Jana Pawła II. I są młodzi ludzie, którzy bardzo chętnie przyjeżdżają, płacą za to i realizują tutaj te spotkania w naszym krakowskim środowisku. 
Oczywiście, istnieje też bardzo ważny Ośrodek Dokumentacji Studium Pontyfikatu Jana Pawła II w Rzymie, na czele tego Ośrodka stoi pracownik naszego Uniwersytetu. I to dzięki ich pomocy organizujemy od lat coś, myślę, też bardzo ważnego dla dziedzictwa Jana Pawła II, mianowicie opracowujemy bibliografię dotyczącą papieża, więc staramy się wszystko to, co się na jego temat ukazuje, zwłaszcza jeśli chodzi o badania naukowe, gromadzić jako bibliografię, jako swoistą pamięć. Można by dużo mówić, chociażby o naszych dziennikarzach, którzy nakręcili ostatnio film Lubię patrzeć jak wschodzi Słońce, ale to może by pani Paulina więcej o tym filmie opowiedziała. Film zrobiono z dosyć dużym rozmachem. Te różne inicjatywy nie słabną, to jest, myślę, jakiś pozytywny dla nas aspekt organizacyjny. Coraz bardziej widzimy zapotrzebowanie na przypominanie postaci, dziedzictwa Jana Pawła II, zwłaszcza ze zbliżającym się stuleciem urodzin. Niedawno podpisaliśmy też umowę z burmistrzem Wadowic, gdzie nasi profesorowie będą w tamtym środowisku proponować pewne spotkania, wykłady dotyczące ich wielkiego patrona, patrona miasta. Tych inicjatyw jest dużo, nam jest pod tym względem łatwiej, bo jesteśmy uczelnią kościelną i uczelnią humanistyczną. $\mathrm{Z}$ takim profilem jaki mamy, jak powiedziałem: teologia, filozofia, historia, nauki społeczne; myślę, że to co dla nas jest niezwykle cenne, to jest właśnie to, że pozostajemy w ramach Kolegium Rektorów Szkół Wyższych Krakowa i że możemy $\mathrm{w}$ ramach tego forum wchodzić w dialog.

Myślę, że to, że podtrzymujemy, to co nam mówił św. Jan Paweł II, że przypominamy jego nauczanie, to jest jeden aspekt, na pewno bardzo ważny, ale mamy świadomość również tego, że lata mijają, że świat się zmienia, że trzeba nam wypracowywać i dążyć do tego, żeby odkryć istotę fenomenu Jana Pawła II i że to nie może być tylko przypominanie wprost jego słów, ale też tego, co jest istotą tego wielkiego sukcesu, jaki odniósł św. Jan Paweł II, również w dziedzinie relacji z uczelniami.

Wprowadzający wykład prof. Andrzeja Nowaka utwierdza mnie w tym, że należy myśleć o tym, że te słowa Fides et Ratio, tzn. ten istotny element dialogu pomiędzy rozumem a wiarą, do którego my się przyznajemy, że on jest jakiś fundamentalny, że Jan Paweł II był też taką postacią. To także powinniśmy podtrzymywać i przypominać oraz starać się tego stylu uczyć, chociaż to oczywiście jest jakiś charyzmat, jakiś dar niezwykły. To już zresztą padło tutaj podczas tej debaty, że Jan Paweł II był kimś, kogo chciało się słuchać. Nawet jeśli często, słuchający, rozmawiający z ojcem świętym nie do końca się zgadzali i nawet jeśli nie zgadzali się z tym, co on mówi, to chcieli go słuchać. Ja dlatego o tym, mówię, bo mamy jako uczelnia kościelna nową konstytucję, którą dał nam papież Franciszek, zresztą konstytucję o nazwie wiele mówiącej Veritatis Gaudium; może to nawet jest cytat z Jana Pawła II. W tym dokumencie papież Franciszek zawarł takie zdanie, dla nas niezwykle istotne jako dla uczelni kościelnej, żeby nawet jeśli nie da się osiągnąć 
$\mathrm{w}$ stu procentach zadania tego przekonywania $\mathrm{w}$ ramach dialogu, to jednak żeby robić wszystko, co w naszej mocy, żeby być w ogóle słuchanym. To jest dzisiaj jakieś szczególne zadanie. I ten fenomen Jana Pawła II w tym zakresie też tak postrzegam. Jak on to robił, że był słuchany, że ludzie, którzy często się z nim zupełnie nie zgadzali, jednak starali się go spotkać, usłyszeć, co on ma im do powiedzenia. I to może też jest jakieś olbrzymie zadanie, jakie przed nami stoi.

Dr Paulina Guzik: Bardzo dziękuję, Księże Rektorze. Przypomniały mi się słowa Pana Profesora o tej autentyczności Jana Pawła II, rzeczywiście po prostu on taki był, autentyczny i rzeczywiście prawdziwie taki, że chciało się go słuchać. Jeszcze odwołam się tu w trybie ad vocem do projektu John Paul II. Studenci amerykańscy, którzy do nas przyjeżdżają, a mam przyjemność prowadzić z nimi zajęcia z komunikacji, zresztą komunikacji wg. Jana Pawła II, mają ogromną wiedzę o Janie Pawle II, którą często zawstydzają naszych polskich studentów, w szczególności wiedzą w zakresie teologii ciała. $\mathrm{W}$ dziedzinie, moim zdaniem, zupełnie jeszcze nieodkrytej wśród młodych ludzi tutaj w Polsce. Młodzi Amerykanie się tym po prostu fascynują. I myślę, że to jest też ogromne zadanie, żeby znaleźć takie punkty, które są jeszcze zupełnie nieodkryte przez młodych ludzi, trochę - ale słabo pamiętających papieża, bo jako dzieci oglądali go z babcią w telewizji albo może mieli szczęście być na któreś pielgrzymce, ale to są ludzie, którzy urodzili się pod sam koniec lat dziewięćdziesiątych ubiegłego wieku. Oni mają prawo nie pamiętać, więc to jest rzeczywiście nasze ogromne zadanie, żeby tę autentyczność papieża pokazać i pokazać też to, dlaczego chcieliśmy go wszyscy słuchać. I jak inspirował w tym wymiarze praktycznym, o którym mówił Ksiądz Rektor.

Sądzę, że teraz jest ten najwłaściwszy moment, aby Pan Rektor opowiedział o Uniwersytecie Ekonomicznym, w jaki sposób Jan Paweł II inspirował ludzi nauki także w wymiarze praktycznym. Jak jego słowa dotyczące Boga, religii, Chrystusa sprawdzały się w tak przyziemnych sprawach jak ekonomia czy finanse; więc bardzo proszę teraz Pana Profesora o kilka słów na temat tego jak ekonomiści tę papieską naukę biorą do siebie i jak z niej korzystają.

Prof. Andrzej Chochól: Szanowni Państwo, przede wszystkim na samym początku chciałem bardzo gorąco podziękować organizatorom za zaproszenie mnie na to ważne spotkanie. Odczuwam to spotkanie jako uroczystość, bo przecież to jest święto społeczności akademickiej w Krakowie, kiedy możemy dyskutować na tak ważne tematy.

Szanowni Państwo, pozwólcie, że na początku trochę zmienię konwencję mojej wypowiedzi w porównaniu do mojego poprzednika i podzielę się moją osobistą refleksją, pokazującą w trochę odmienny sposób obecność ojca świętego w społeczności akademickiej, w społeczności Krakowa. Otóż chcę powiedzieć, że uro- 
dziłem się i swoje dzieciństwo spędziłem w samym centrum Krakowa. Z jednego okna widziałem fragment Wawelu, $\mathrm{z}$ drugiego okna naszego mieszkania widziałem fragment kościoła Bożego Ciała, obecnie bazyliki Bożego Ciała. I tam też byłem ministrantem. Kiedy jako mały chłopiec służyłem do mszy, kościół ten był pod jurysdykcją biskupa Karola Wojtyły. On przyjeżdżał od czasu do czasu na wizytację kościoła. Kościół był wtedy odpowiednio przygotowany, pamiętam pewną nerwowość księdza proboszcza, wówczas księdza Grabiszewskiego, towarzyszącą przygotowaniom do podjęcia biskupa w naszym kościele. I muszę powiedzieć, że słuchałem wówczas biskupa Wojtyły, ale go wtedy nie słyszałem, nie rozumiałem tych kazań do końca. Kiedy byłem już znacznie starszy, w młodzieńczych latach przechodziłem u podnóża kopca Kościuszki i w pewnej odległości zobaczyłem postać nieco przygarbioną, skupioną zbliżającą się w moim kierunku. Zauważyłem, że to właśnie ksiądz, już wówczas kardynał, Wojtyła. Kiedy przechodziliśmy już blisko siebie, skłoniłem głowę, żeby go powitać go, oddać mu szacunek i zauważyłem wtedy, że on nie chciał mnie tylko zobaczyć, on chciał mnie poznać. Zatrzymał się, zaczął ze mną rozmawiać, zapytał kto ja jestem, co tutaj robię i wtedy zobaczyłem tę głębię tego człowieka. On nie chce tylko widzieć, on chce poznać ludzi i wejść głębiej. I kolejne takie wydarzenie w moim życiu z kontaktu z Janem Pawłem II. Kiedy już jako papież 17 czerwca 1979 rok przyjechał do Polski, ja już byłem po obronie pracy habilitacyjnej. I podczas tej pielgrzymki na naszą uczelnię przyjeżdża wielki Jan Paweł II, ojciec święty. Chciałem Państwu pokazać ten moment, kiedy on przyjeżdża na naszą uczelnię i witamy go przed budynkiem. Ojciec święty zmierzał wtedy papamobile na cmentarz Rakowicki, żeby odwiedzić swoich rodziców. I wówczas w czasie tego krótkiego spotkania z nami wypowiedział znamienne słowa: „Zawsze zastanawiałem się nad tym skąd ta koniunkcja, po jednej stronie karmelici bosi, po drugiej Akademia Ekonomiczna", bo wówczas tak się nazywaliśmy. I wypowiada takie trzy uderzające słowa: „ekonomia na bosaka”. „Ekonomia na bosaka” to określenie do dzisiaj funkcjonuje w pamięci naszej społeczności. „Ekonomia na bosaka” - czy to był tylko żart? Teraz, z perspektywy lat, można powiedzieć, że nie do końca.

Zmierzam już tutaj w kierunku tych refleksji, które dzisiaj tutaj na tej sali wybrzmiały, a więc w kierunku uniwersytetów dzisiaj i pytania o ich służbę prawdzie. Służba prawdzie, pan profesor Wojciech Nowak powiedział, że ojciec święty w specyficzny sposób mówił rzeczy oczywiste i głęboko prawdziwe. I okazuje się dzisiaj, jak te rzeczy, wydawałoby się oczywiste, są niesłychanie ważne. Papież na różnych spotkaniach mówił o nich różnymi słowami. Słowa wydawałoby się oczywiste, ale jakże ważne. Jak popatrzymy na tę prawdę, prawdę, która powinna być krzewiona na uniwersytetach, to trzeba zauważyć, że niektóre prawdy są jednoznaczne, nie da się ich przekłamać, czy przeinaczyć; trudno byłoby niezgodnie ze stanem faktycznym omawiać czy w jakiś sposób interpretować prawa fizyki, są one bowiem 
jednoznaczne w tych naukach podstawowych. Ale już z ekonomią jest nieco inaczej. Może być partykularnie wykorzystywana i to stanowi niebezpieczeństwo. Wracam tu do tych trzech słów „ekonomia na bosaka”, jak je rozumiem, żebyśmy służyli prawdzie i żebyśmy byli odważni w krzewieniu tej prawdy.

Uniwersytet, jak to już wielokrotnie powiedziano na tej sali, funkcjonuje jako wspólnota, stąd też to odwoływanie się papieża do tej wspólnoty. Podkreślając tę wspólnotę i fakt, że uniwersytety z pewnością są tą wspólnotą, warto zastanowić się, jakie tej wspólnocie zagrażają niebezpieczeństwa, przed jakimi staje zagrożeniami? Myślę, że jednym z podstawowych takich czynników zagrożenia jest brak czasu na refleksje, brak czasu na tę agorę, o której już tu była mowa. My to jakoś robimy, ale robimy to bardzo szybko, dynamicznie. Czas niesamowicie szybko w tej chwili biegnie. Wydaje się, że on biegnie innym trybem niż wcześniej, te 30 lat temu. I właśnie ten pośpiech i brak czasu na refleksje, na twórcze i głębokie spory stanowią dla nas pewne niebezpieczeństwo.

Szanowni Państwo, z pewnością misja uniwersytetu musi łączyć się z pasją. Tak pięknie o tym mówił ojciec święty: „Młody człowiek pragnie odnaleźć siebie samego dlatego szuka, czasem burzliwie szuka prawdziwych wartości i ceni tych ludzi, którzy ich nauczają i według nich żyją". Któż z nas nie miał w życiu i nie wspomina z wdzięcznością takiego człowieka (kapłana, nauczyciela, profesora lub przyjaciela), który umiał przed nim odsłonić na nowo świat wartości i wzbudzić dla niego trwały entuzjazm, czy nawet nadać cały kierunek życiu. Szanowni Państwo, jakże niesłychanie ważna jest ta pasja w życiu twórczym człowieka, zwłaszcza człowieka młodego, ale także w życiu każdego z nas. Kultura, wychowanie, piękno to rzeczy bezcenne. I znów tutaj wspomnę fragment homilii wygłoszonej przez ojca świętego podczas mszy św. na terenie uniwersytetu w Laval w 1984 roku; znamienite i ważne słowa, które wówczas wypowiedział, niesłychanie ważne w życiu naszych uniwersytetów. Myślę, że jego idee krzewimy również poprzez różne działania nie tylko poprzez to, że kształcimy na pierwszym, drugim stopniu, w szkołach doktorskich, ale również przez to, że podejmujemy inne działalności, nieco odmienne w charakterze, żeby zachować pewien koloryt na naszych uczelniach, a więc istnieją chóry, a podejmujemy działania sportowe, snujemy wspomnienia. Taki był na przykład piękny wczorajszy dzień, dzień wspomnień o osobach, które odeszły z naszych uniwersytetów. Zatem ta zróżnicowana działalność naszych pracowników, naszych studentów, którą tutaj państwu, chociaż fragmentarycznie, chciałem przedstawić: organizacja różnych wystaw tematycznych, noc kinowa, przegląd kapel rockowych, a więc w różnych obszarach te działania uniwersytetu na wzór działań renesansowych są podejmowane. I one są dla tych młodych ludzi, dla naszych studentów bardzo odkrywcze. Chodzi o to, żeby im pokazać tą barwę życia po to, żeby we właściwych kierunkach potem oni podążali. Tu należy także troska o naturę. Szanowni Państwo, to przecież niezmier- 
nie ważny element naszego życia. Jan Paweł II nawiązywał często w swoich wypowiedziach do tych słów z Biblii: „czyńcie sobie Ziemię poddaną”, wyjaśniał jak je rozumieć. One znaczą też, że trzeba respektować prawa Ziemi, prawa natury i w tej dziedzinie, w trudzie umiejętnego opanowania sił przyrody i mądrego gospodarowania jej zasobami środowisko naukowe ma wielkie pole działania. Nauka, jak Państwo sami wiecie, ma wielkie zadanie do spełnienia i myślę, że tutaj pokazanie naszym słuchaczom, w jaki sposób możemy dbać o nasze społeczeństwo, w jaki sposób musimy dbać o naszą Ziemię nawet poprzez drobne kroki, które myślę, że na każdej uczelni wykonujemy. Przykładowo na naszym uniwersytecie organizujemy takie akcje: Tydzień ekologii czy Rowerem do pracy, albo chociażby uczymy wykorzystania banerów, które są do wyrzucenia, jako toreb promujących nasz Uniwersytet. Takimi drobnymi kroczkami staramy się uczyć tych młodych ludzi i również samych siebie, w jaki sposób postępować, aby nie zaśmiecać naszego świata. Odpowiedzialność za drugiego człowieka, to także niesłychanie ważny element w życiu uniwersytetów. Przytoczyłem tutaj również przemówienie ojca św. adresowane do rektorów uczelni w Polsce, które wygłosił na spotkaniu w Toruniu w 1999 roku. Odpowiedzialność za drugiego człowieka wyraża też piękna inicjatywa skierowana do osób niepełnosprawnych, podejmowana w naszej społeczności akademickiej, a właściwie we wszystkich społecznościach naszych uniwersytetów. Są to działania na rzecz wsparcia psychologicznego dla tych osób. W tym zakresie organizujemy na przykład dni integracji. Albo inne wspaniałe wydarzenie, polegające na oddawaniu krwi dla potrzebujących, znane pod nazwą „Wampiriada” - może ta nazwa budzi pewne kontrowersje. Studenci i nasi pracownicy oddają ogromne ilości krwi, które tak bardzo są potrzebne. To niesłychanie ważne.

Szanowni Państwo, jeszcze jedna kwestia, mianowicie: społeczna odpowiedzialność biznesu. Tutaj mówiliśmy przede wszystkim o społeczności studentów, ale nie zapominajmy, jak bardzo istotna dla naszego uniwersytetu pozostaje społeczna odpowiedzialność biznesu. To nie może być tak, że ekonomia uczy jedynie jak maksymalizować zyski. To nie powinno być tak, to przede wszystkim powinna być ta społeczna odpowiedzialność, a więc maksymalizacja - tak, ale nie wszelkimi środkami, tylko w taki sposób, żeby to było bezpieczne i w taki sposób, który jest etyczny. I tego bezwzględnie powinniśmy uczyć naszych studentów.

Szanowni Państwo, jest takie hasło: „studiuj, doświadczaj, żyj”. W tym roku pod takim hasłem inaugurowaliśmy dziewięćdziesiąty piąty rok istnienia Uniwersytetu Ekonomicznego w Krakowie. Więc chcemy, żeby ten Uniwersytet był matką dla naszych studentów, dla naszych pracowników, dla ludzi, którzy kiedyś w nim pracowali. Żeby to była właśnie wspólna rodzina. Żebyśmy czuli się odpowiedzialni jedni za drugich i za nasze biznesy, żebyśmy byli potrzebni na naszym rynku. Chodzi o to, żeby to nie były puste hasła, tylko żeby były wypełnione treściami 
związanymi z głęboko rozumianą etyką. I żebyśmy patrzyli na te wszystkie kwestie poprzez słowa i poprzez nauczanie naszego ojca świętego Jana Pawła II.

Dr Paulina Guzik: Dziękuję, Panie Profesorze, za tę refleksję i też za to połączenie ekonomii z etyką, bo to jest szalenie ważne w kontekście społecznej odpowiedzialności biznesu. Faktycznie naukę społeczną Jana Pawła II możemy tu dobrze wykorzystać. Przede wszystkim jednak dziękuję za tę refleksję ludzką, także za podkreślanie wagi idei spotkania, którą realizują państwo na uniwersytecie. Możemy się tu odwołać do tomistycznej idei dziedzińca pogan, gdzie wszyscy spotykają się i dyskutują, choćby się ze sobą nie zgadzali. W tym świecie dzisiejszych studentów, co widzę też po naszych studentach, nie dla wszystkich podstawową rozrywką jest to, co było nią dla środowiska Karola Wojtyły. Chodzenie w góry z księdzem, do którego mają ogromny szacunek i zwykłe zaufanie, którego też poza wszystkim bardzo lubią, czy nawet kochają - to nie jest model rozrywki ani model spędzania wolnego czasu dla naszych studentów. Musimy zatem w inny sposób do nich dotrzeć, bo ich rozrywki są zupełnie inne i te wszystkie wymienione tutaj inicjatywy są rzeczywiście bardzo piękne. W Świadku nadziei Georga Weigla siostra prof. Zofia Zdybicka wspomina, jak to na KUL-u Wojtyła śmiał się, że był jedynym profesorem, który uczy się od studentów. Bo jak już jako biskup miał mało czasu, żeby czytać nowości filozoficzne, to studenci czytali i mu referowali. Zastanawiam się, jak przyszli nauczyciele czerpią z dziedzictwa Jana Pawła II i czy jest to też wzajemne słuchanie się. Tak jak Wojtyła słuchał swoich studentów, to czy my dziś też naszych studentów słuchamy.

Prof. Kazimierz Karolczak: Szanowni Państwo, zastanawiałem się przez chwilę, czym ja się mogę pochwalić. Rektor Zyzak szeroko opowiedział, jak Uniwersytet Papieski Jana Pawła II prowadzi badania nad myślą Jana Pawła II. Rektor Chochół wspomniał, że wychowywał się z widokiem na Wawel i kościół krakowski. Ja do Krakowa przybyłem dopiero w połowie lat 70., Wawelu, dorastając, nie oglądałem, kościół też raczej inny widziałem - wielkopolski. Natomiast zacząłem myśleć o tym, w jaki sposób Uniwersytet Pedagogiczny może czerpać i czerpie z myśli Jana Pawła II, mimo że Jan Paweł II nigdy na naszym uniwersytecie nie był. Uniwersytet Pedagogiczny w trakcie swej ponad siedemdziesięcioletniej już historii przeszedł ogromną ewolucję. Powołany został do kształcenia nauczycieli i myślę, że tą właśnie misją, która w pierwszym rzędzie jest wpisana w Uniwersytet Pedagogiczny, najbardziej wiąże się z tym pierwszym nauczycielem, największym nauczycielem, Janem Pawłem II. Jan Paweł II był nauczycielem całe swoje życie. I bez względu na to, czy tak jak tu wielokrotnie mówiliśmy dzisiaj, niezależnie od tego, czy tylko go słuchaliśmy, czy go rzeczywiście słyszeliśmy, wszyscy jednak pamiętamy, że on był tym nauczycielem. Był dla wszystkich, nie tylko dla tych, 
którzy na co dzień chodzili do kościoła. Kiedy Jan Paweł II był z pielgrzymką w Polsce, to te tłumy gromadziły także ludzi, którzy od Kościoła byli stosunkowo daleko. Dlaczego chcieli przyjść? Po to, żeby go słuchać. I jeżeli my kształcimy nauczycieli, a przeszliśmy w tym zakresie dużą ewolucję, to staramy się to robić wspólnie z tymi uczelniami, które również prowadzą podobne kształcenie. Przywołam tylko jeden przykład. Kilka lat temu, na tej sali, spotkaliśmy się z ministrem Gowinem. Z rektorem Nowakiem mówiliśmy wtedy, jak kształcić nauczycieli, co w tym trzeba zmienić. Dlaczego kształcenie nauczycieli jest takie ważne? Dlaczego musimy dbać o to, żeby to nie było tylko przekazywanie wiedzy, ale żeby nauczyciel był przewodnikiem? Czy Jan Paweł II nie był dla nas przewodnikiem? Był nim dla nas przez cały swój pontyfikat! I myślę, że ważne jest kształcenie nauczycieli w takim duchu - miej wiedzę, ale bądź przewodnikiem. Tak ucz, żeby ktoś cię słyszał, żeby uczeń szedł za tobą. I taka postawa jest też chyba powiązana $\mathrm{z}$ całym życiem Jana Pawła II.

Moje osobiste wspomnienia są mało znaczące i dotyczą jeszcze czasów, kiedy Karol Wojtyła był kardynałem; to były już ostatnie lata jego bycia w Krakowie. To były jedynie msze św. na Wawelu, ale to potem wyczekiwanie na kolejną pielgrzymkę. Godziny stania przy drodze, na Błoniach. Czekanie na słowa, które powie. Myślę, że ci, którzy słuchali Jana Pawła II i go słyszeli, a potem zostali nauczycielami, mówię o swoim środowisku, bo ja też jestem nauczycielem, to bardzo wiele z tych spotkań wykorzystali. I chyba wykorzystują do dzisiaj. Natomiast nawiązując do pytania, jak dzisiaj młodzież pamięta Jana Pawła II na Uniwersytecie Pedagogicznym, to chyba nie będę tutaj optymistyczny. Jest u nas podobnie jak na wielu innych uczelniach. Rozmawiałem w przerwie z kilkoma osobami, mówiliśmy o tym, że pokolenie JP2 jakby zamknęło się przed już kilku laty. Ta młodzież, która dzisiaj studiuje nie może pamiętać Jana Pawła II z autopsji. Możemy jej tylko mówić o Janie Pawle II. Myślę, że najwięcej jest w stanie dowiedzieć się o nim na Uniwersytecie Papieskim Jana Pawła II, to jest oczywiste. Natomiast na Uniwersytecie Pedagogicznym, w moim rozumieniu, ważne jest to, żeby tak kształcić przyszłych nauczycieli, aby myśl Jana Pawła II była tam obecna, niezależnie od tego, czy się ją przywołuje z konkretnej encykliki, czy tylko się pamięta, że on to powiedział. Bardzo ważne podczas naszej debaty było przywołanie słów Jana Pawła II z Sydney z 1986 roku, że nie można na uniwersytecie uczyć bez prowadzenia badań, że trzeba podejmować badania. Czyli my musimy być i badaczami, i nauczycielami, musimy to zawsze łączyć.

Znajdujemy się teraz w trochę dziwnej sytuacji, gdyż przygotowywana przez kilka lat Konstytucja dla nauki - reforma szkolnictwa wyższego - podzieliła środowisko. Jako rektorzy dyskutowaliśmy z twórcami tej ustawy, przekonywaliśmy do wielu rzeczy. Z pewnych założeń jesteśmy zadowoleni, z innych jednak, nie. Wielokrotnie dawaliśmy temu wyraz, ale skoro Konstytucja dla Nauki weszła w życie, 
to nas zobligowało do wprowadzenia jej przepisów na nasze uniwersytety. To nie tylko wiązało się z ogromnym wysiłkiem, ale wiązało się także z dużymi emocjami, które temu towarzyszyły. Nie mogło być inaczej w sytuacji, kiedy na niektórych uniwersytetach następowało przebudowanie struktury. Mówię tu o swoim uniwersytecie, o Uniwersytecie Pedagogicznym, gdzie zniknęły tradycyjne wydziały, a w to miejsce powstały wydziały stricte naukowe. Czyli w efekcie zostało oddzielone kształcenie od badań. Wydziały mają charakter dziedzinowy. W tylu dziedzinach, w których prowadzimy badania, w tylu utworzyliśmy struktury wydziałowe, na których istnieją rady dyscyplin z ich przewodniczącymi. Natomiast kształcenie sprowadzono na poziom instytutów, obudowanych radami naukowymi instytutu. Oczywiście, w jednych i drugich strukturach są ci sami ludzie, czyli trzeba badać, żeby prowadzić kształcenie. Cała nasza walka $\mathrm{z}$ dwoma ministerstwami toczyła się przez ostatnie lata o to, żeby nauczycieli kształcili ci, którzy prowadzą badania nad metodyką nauczania, a nie, żeby to było odtwórcze. Wiemy, że gdzieś od połowy lat 90., kiedy mieliśmy do czynienia z wchodzeniem wyżu demograficznego do szkół, potrzeba coraz więcej nauczycieli. Zaczęto ich kształcić także na kursach prowadzonych przez różnego typu stowarzyszenia, które grupowały czynnych nauczycieli. Czyli praktyk kształcił następnego nauczyciela. To było bardzo odtwórcze, to nie godziło się w żaden sposób z tym, o czym myślał Jan Paweł II, żeby kształcili ci, którzy prowadzą badania. Bo tylko wtedy jest postęp, bo tylko wtedy możemy pokazywać coś nowego. Jeżeli powielamy tylko to, co umiemy, to tam kończy się postęp, a zaczyna się rutyna. Jeżeli nauczyciel będzie kształcony rutynowo, to tak samo będzie kształcił także młode pokolenie.

Dr Paulina Guzik: Cieszę się, że Pan Profesor skończył tą krytyką rutyny, bo Jan Paweł II był papieżem, który absolutnie nie znał słowa rutyna. Bardzo Państwa proszę o pytania do naszych prelegentów i panelistów. Myślę, że to też będzie bardzo ciekawa część dyskusji. Jakie są Państwa przemyślenia?

Prof. Wojciech Nowak: Szanowni Państwo, mam taki charakter, że bardzo lubię czasami sprowokować dyskusję. Popatrzcie Państwo, jak jesteśmy niekonsekwentni, ja też. Powiedziano tutaj słusznie, że nie ma nic gorszego niż polityczna poprawność - political correctness. W całym dzisiejszym dniu i w naszych wspaniałych wypowiedziach nie byliśmy nigdy w niezgodzie $\mathrm{z}$ tym, co powiedział Jan Paweł II. Nie byliśmy, albośmy tego nie powiedzieli. Czy wyobrażacie sobie Państwo w Uniwersytecie rektora Zyzaka dyskusję o kontrowersyjności poglądu Jana Pawła II na...? Nie będę teraz dawał przykładów, one są. Bardzo się boję, żebyśmy nie zrobili z Jana Pawła II lukrowanej postaci, która jest genialna we wszystkim. Jan Paweł, przepraszam bardzo, wtedy by się w grobie obrócił, bo zawsze przed 
czymś takim uciekał. To, co tu tak mocno wybrzmiało, że muszą być kontrowersje i muszą być dyskusje jest fundamentalne.

Pójdźmy jeszcze dalej. Przypomnę tu bardzo kontrowersyjne zdanie o roli rektorów, nie dziwcie się Państwo, ja kończę kadencję więc mnie to nie bardzo dotyczy. Rektor Uniwersytetu Ekonomicznego, więc najważniejszej, jeśli idzie o finanse uczelni uczy młodych ludzi dobrze pracować i dobrze zarabiać. Korporacyjność, ale czy ona jest zła? A ja będę jeszcze bardziej przekorny, budżet Uniwersytetu Ekonomicznego nie wiem jaki jest więc będę strzelał. Załóżmy $500 \mathrm{mln}$ zł, naszych pieniędzy. Istnieje, jak słyszeliśmy, społeczna odpowiedzialność biznesu i co rektor ma zrobić? Odpowiada za wydanie $500 \mathrm{mln}$ naszych pieniędzy, bo nauka kosztuje gigantyczne pieniądze. Jeżeli nie sprawdzi jakie będzie miał efekty, to zmarnuje te nasze pieniądze, wypracowane przez nas. To nie są prywatne pieniądze, to są pieniądze z podatków, naszych podatków. Jak ma ocenić, czy jego pracownicy wykonują dobrze swoje obowiązki, czy źle? Bez parametryzacji, przez peer review? To nie jest takie proste.

Szanowni Państwo, ja zgadzam się w stu procentach w tym aspekcie z Panem Profesorem, że czasami łatwo jest sprowokować. Ta wspomniana praca trzech wybitnych fachowców pokazała pewną niebezpieczną ścieżkę. W naukach medycznych, mnie z kolei bliższych, dziesięć lat temu była taka praca człowieka, oczywiście z Oxfordu. Zrobili badania jak toksyczne są pewne substancje zależnie od dawki. No, oczywiście te wszystkie zwierzaki umierały, potem każdy, kto robił podobne doświadczenia pisał, że tamci wykazali, że w takiej dawce zwierzak zdechnie, w konsekwencji ta pierwsza publikacja miała ogromną cytowalność. To jest absurd. Posłuchajcie Państwo, ja co roku oglądam Ig-noble w Harwardzie - najlepszy uniwersytet świata, polecam. Nie boimy się tego, wystawiamy się na śmieszność, dlaczego? Dlatego, że w nauce, tak jak w sztuce - mówię o prawdziwej nauce i prawdziwej sztuce - tylko 10\%, może mniej, odnosi sukces. Ale wydatki, te $500 \mathrm{mln}$ u pana rektora, wyobraźcie sobie, że $450 \mathrm{mln}$ idzie do kosza. Społeczna odpowiedzialność pada na rektora. To nie są takie proste sprawy. Może być jeszcze gorzej. W naukach medycznych poznanie genomu kosztowało ok. 3,5 mld dolarów. No i poznaliśmy ten genom, wszyscyśmy się zachwycili, że już wszystko wyleczymy. Oczywiście, że nie. Okazało się, że to nie takie proste.

I najważniejsza rzecz, którą tu Pani powiedziała. Szanowni Państwo, mówimy o Janie Pawle II. Ja pamiętam, jak tutaj w tej sali zrobiliśmy spotkanie w rocznicę odwiedzin Jana Pawła II w kolegiacie św. Anny. Puściliśmy film z tego okresu. Ja myślałem, że tu się nie będzie dało wejść, że przyjdą tłumnie zwłaszcza ci młodzi ludzie, którzy, nie tak jak my w większości, mieli możność spotkania, bycia na pielgrzymce, zobaczenia papieża. Nie przyszli. Czyja to jest wina? Nie Jana Pawła II, ale nasza. 
Dr Paulina Guzik: Bardzo dziękuję, Panie Profesorze i w takim razie myślę, że już zmierzając do finału naszej dyskusji, poproszę jeszcze o wypowiedzi ad vocem. Księdza Profesora poproszę zatem o słowo ad vocem do kwestii sporu i dyskusji w sporze. Natomiast Pana Profesora o odwołanie się do społecznej odpowiedzialności wydawania uczelnianych pieniędzy

Ks. prof. Wojciech Zyzak: Ja bym chciał bardzo Pana Rektora, gospodarza naszego, uspokoić. Mianowicie chciałbym go uspokoić przypomnieniem, że jak co niedzielę na mszy św. wypowiada Credo, to ono powstało w wyniku wielowiekowych kłótni w Kościele. I czasami w efekcie olbrzymich dyskusji, olbrzymich walk. Jeśli chodzi o postać naszego najwybitniejszego Polaka i profesora Jana Pawla II, to pamiętajmy, że św. Jan Paweł II w swoim nauczaniu nie zdefiniował żadnego dogmatu, w związku z tym jego nauczanie jest, mówimy oczywiście, ponadczasowe na tyle, na ile ono jest ewangeliczne, na ile sięga do tych ewangelicznych korzeni. Natomiast w oczywisty sposób jesteśmy wszyscy w nurcie historii i czasy się zmieniają, ludzie się zmieniają, język się zmienia. My to wszystko doskonale wiemy również na Uniwersytecie Papieskim i w związku z tym, Panie Rektorze, proszę się nie bać. My oczywiście dyskutujemy o tym wszystkim, czego nas uczył i o aktualności nauczania św. Jana Pawła II. Pewnie dyskutujemy tym bardziej, im bardziej przychodzą nowe pontyfikaty, nowi charyzmatyczni przywódcy Kościoła z różnymi nowymi tematami i ta wierność dyskusji na Uniwersytecie Papieskim i to, że jesteśmy na nią otwarci, jest przez nas rozumiana jako wierność Janowi Pawłowi II.

Dr Paulina Guzik: Bardzo dziękuję, Księże Rektorze i proszę, Panie Profesorze.

Prof. Andrzej Chochół: Szanowni Państwo, może zacznę żartobliwie, przede wszystkim wiem, że na tej sali, często padały prorocze słowa, chciałbym bardzo, aby to, co powiedział rektor Nowak było tymi proroczymi słowami, żeby ten nasz uniwersytet miał te $500 \mathrm{mln}$, bardzo bym się cieszył.

A teraz bardziej poważnie. Tak to prawda, i myślę, że Pan Profesor właśnie w imieniu nas wszystkich to wyraził, że my wszyscy jesteśmy odpowiedzialni za przyszłość, a jednocześnie za to, że mamy te powierzone nam pieniądze, można powiedzieć pieniądze społeczne, i z nich czerpiemy, i chcemy je jak najlepiej wykorzystać. Z jednej strony, oczywiście, możemy się cieszyć, że kształcimy tak dobrze, że już na piątym roku niemal wszyscy studenci pracują. Korporacje wyszukują naszych absolwentów, żeby ich zatrudnić. Właściwie w stu procentach w pierwszych czterech miesiącach od ukończenia studiów wszyscy nasi absolwenci znajdują zatrudnienie. To dotyczy nie tylko sytuacji z dzisiaj, kiedy dzięki dobrej koniunkturze rynek pracy nie należy do pracodawcy, ale jest rynkiem pracownika. Tak było 
już wcześniej, kiedy były duże trudności z pracą. A nasi studenci raczej nie mieli kłopotów ze znalezieniem zatrudnienia. $Z$ drugiej strony, możemy popatrzeć na te duże korporacje, kto nimi zarządza - w wielu przypadkach to są nasi absolwenci. Jest to też jakiś też powód do radości. To wszystko jednak może być bardzo złudne, spowodowane tym, że jest akurat taki moment, panuje niezła koniunktura gospodarcza, zachodzą systemowe przemiany gospodarcze, do przeprowadzenia których osoby z taką ogromną wiedzą są szczególnie potrzebne. Myślę jednak, że wszyscy z nas tak jak tutaj siedzimy - wszyscy rektorzy, to mamy świadomość tego, że każdy obszar, każda dyscyplina wiedzy jest tak samo potrzebna. I dlatego powinniśmy dbać o to, żeby w maksymalny sposób ten fakt wykorzystać. Sądzę, że właśnie ta myśl Jana Pawła II, która mówi jednoznacznie, w pierwszej kolejności o prawdzie, jako o tym fundamencie nauki, że ta myśl powinna się przebijać się, a jej praktykowanie powinno przynosić efekty w postaci dobrego wykształcenia oraz maksymalnego wykorzystania pieniędzy, którymi dysponujemy.

Dr Paulina Guzik: Bardzo dziękuję i jeszcze na koniec spiritus movens naszych dzisiejszych uroczystych debat, ojciec Jarosław Kupczak.

O. Jarosław Kupczak OP: Szanowni Państwo, myślę że wszyscy mamy wrażenie, że ta bardzo ważna, doniosła debata na niezwykle ważny dla nas wszystkich temat jest zaledwie początkiem rozmowy. Cóż, obowiązkiem organizatora jest w pewnym momencie zakończyć każdą, nawet najlepszą, konferencję. Chcę bardzo serdecznie podziękować wszystkim, dzięki którym ta debata mogła się dziś odbyć. Dziękuję Magnificencjom Panom Rektorom, dziękuję panu profesorowi Ziejce i panu profesorowi Nowakowi za ich znakomite wystąpienia. Dziękuję tym wszystkim, którzy przygotowali książki na ten dzisiejszy dzień, którzy na różny sposób przyłożyli się do sukcesu tej konferencji. Wreszcie dziękuję Państwu, wszystkim uczestnikom tej dzisiejszej debaty. Zanim wyrażę wdzięczność naszym panelistom, zanim podziękujemy oklaskami wszystkim rektorom, chcę Państwa zaprosić na ostatnie wydarzenie tegorocznych Dni Jana Pawła II. Mianowicie dzisiaj o godz. 17.00 w sanktuarium św. Jana Pawła II w Łagiewnikach odbędzie się msza św., której będzie przewodniczył ks. kardynał Stanisław Dziwisz. Wygłosi do nas homilię i wówczas nastąpi ogłoszenie nagród przyznanych, tak jak każdego roku, w konkursach literackim i fotograficznym XIV edycji Dni Jana Pawła II. Raz jeszcze Magnificencjom, Panom Rektorom, oczywiście także Pani dr Paulinie Guzik za znakomite prowadzenie dziękuję. 


\section{ANEKS II}

NAGRODZONE W KONKURSIE LITERACKIM PRACE STUDENCKIE 
